\title{
Survival and growth of tuatara Sphenodon punctatus following translocation from the Cook Strait to warmer locations in their historic range
}

\author{
Stephanie J. Price, Kristine L. Grayson \\ Brett D. Gartrell and Nicola J. Nelson
}

Abstract Post-translocation monitoring is fundamental for assessing translocation success and identifying potential threats. We measured outcomes for four cohorts of tuatara Sphenodon punctatus translocated to warmer climates outside of their ecological region, to understand effects of climate warming. Translocation sites were on average $2-4{ }^{\circ} \mathrm{C}$ warmer than the source site. We used three short-term measures of success: survival, growth and reproduction. Data on recaptures, morphometric measurements, and reproduction were gathered over 2.5 years following release. Although decades of monitoring will be required to determine longterm translocation success in this species, we provide an interim measure of population progress and translocation site suitability. We found favourable recapture numbers, growth of founders and evidence of reproduction at most sites, with greater increases in body mass observed at warmer, less densely populated sites. Variable growth in the adult population at one translocation site suggested that higher population density, intraspecific competition, and lower water availability could be responsible for substantial weight loss in multiple individuals, and we make management recommendations to reduce population density. Overall, we found that sites with warmer climates and lower population densities were potentially beneficial to translocated tuatara, probably because of enhanced temperature-dependent and density-dependent growth rates. We conclude that tuatara could benefit from translocations to warmer sites in the short term, but further monitoring of this long-lived species is required to determine longer-term population viability following translocation. Future vulnerability to rising air temperatures, associated water availability, and community and ecosystem changes beyond the scope of this study must be considered.

Keywords Climate change, conservation management, conservation translocation, population density, range-

Stephanie J. Price (Corresponding author) and Nicola J. Nelson School of Biological Sciences, Victoria University of Wellington, Kelburn Parade, Wellington 6012, New Zealand. E-mail steph.joyce.price@gmail.com

Kristine L. GRAYSON Department of Biology, University of Richmond, Richmond, USA

Brett D. Gartrell Institute of Veterinary, Animal and Biomedical Sciences, Massey University, Palmerston North, New Zealand

Received 26 July 2017. Revision requested 21 September 2017.

Accepted 11 January 2018. First published online 11 September 2018. restricted, reintroduction, Rhynchocephalia, Sphenodon punctatus

\section{Introduction}

nthropogenic climate change is predicted to have subAstantial effects on biodiversity (IPCC, 2014), with poorly dispersing and cold-adapted species at particular risk from rising air temperatures (Deutsch et al., 2008; Miller et al., 2012). Translocation, the human-mediated movement of organisms from one location to another, can negate obstacles to dispersal, move populations into more favourable climatic environments, and reduce the likelihood of species extinction (IUCN/SSC, 2013). Population restorations and reinforcements are translocations within known ranges. Translocations involving assisted colonizations and ecological replacements are, however, more controversial because they move species outside known ranges, but are becoming necessary to support species navigating climate change (Seddon, 2010).

Successful translocations have been documented for a range of taxa, but these have largely dealt with current climates, rather than the consequences of increasing temperature and changes in water availability associated with climate change for future population viability (Seddon et al., 2012; IPCC, 2014). Reptile translocations have had comparatively little attention compared to those of birds and mammals and lower success rates (Germano \& Bishop, 2008). As ectotherms, reptiles are particularly vulnerable to climate change, although higher latitude species could initially benefit from warming air temperatures (Huey et al., 2012). Reptile translocations for conservation purposes often include species with long life spans, low reproductive output and slow sexual maturation (Germano \& Bishop, 2008), for which it can take decades to confirm success as measured by a self-sustaining population. Therefore, interim measures are important for predicting likely success of translocated populations in current and climate change scenarios (Miller et al., 2014).

Tuatara are long-lived, cold-adapted, New Zealand endemic reptiles and the sole extant representatives of the Rhynchocephalia (Cree, 2014). Holocene subfossil records show that tuatara were formerly widespread throughout New Zealand (Fig. 1), but the introduction of mammalian 


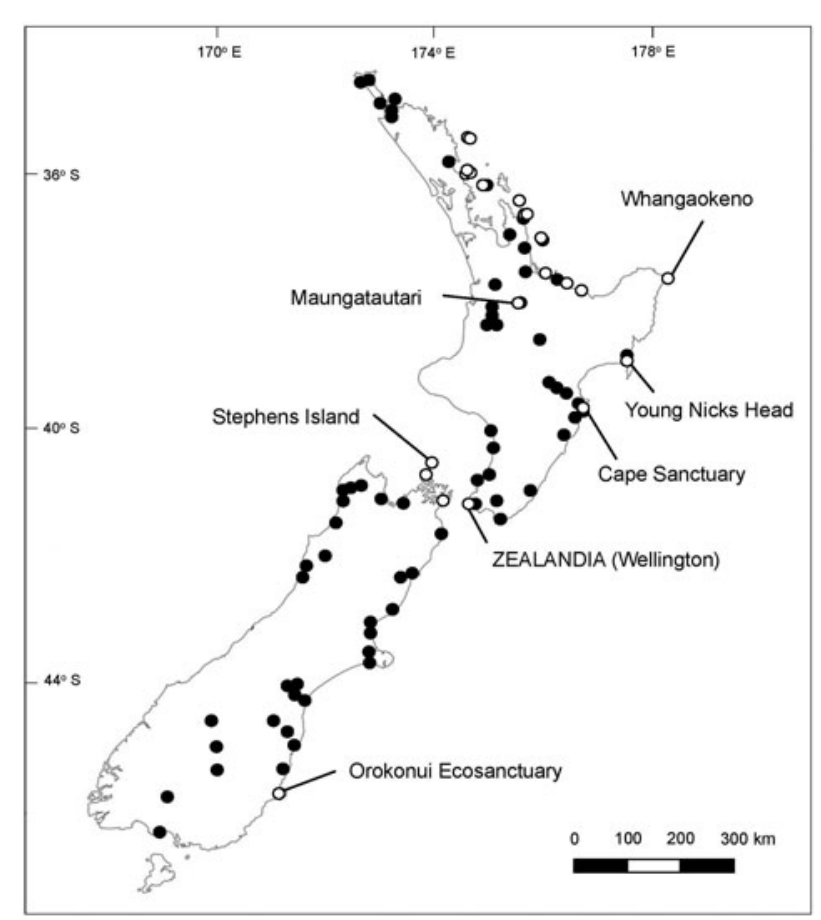

FIG. 1 New Zealand, showing locations where Holocene subfossil remains of tuatara Sphenodon punctatus have been found (black circles) and island groups/areas in which tuatara populations, both translocated and naturally occurring, are currently present (white circles). Sites reported on in this study include the October 2012 translocation sites (Cape Sanctuary, Maungatautari, Young Nicks Head and Whangaokeno), the source site (Stephens Island) and comparison site (ZEALANDIA). Map adapted from Miller et al. (2012).

predators led to the extinction of all mainland North and South Island tuatara populations (Cree \& Butler, 1993). Translocations to establish new populations on predatorfree islands have been important for tuatara conservation (Towns et al., 2016), but their slow reproductive cycles (Cree et al., 1992) mean that the population viability and success of early translocations cannot yet be fully ascertained, although short term indicators such as survival and growth of founders and recruitment are available (Miller et al., 2012). Remnant and reintroduced island populations represent only a small fraction of the former range of tuatara and offer a limited range of environmental conditions, whereas the mainland of New Zealand presents greater habitat diversity and a wider range of environmental conditions to offset early effects of climate change.

We used the first large-scale mainland translocations of tuatara to study population-level responses to warmer climates, with the aim of informing future conservation efforts. These five translocations returned tuatara to sites within their historical range, but four were the first to move tuatara outside their current ecological region to new climatic regions with comparatively warmer, drier climates (Fig. 2), which serve as surrogates for climate change.
The fifth translocation moved tuatara to Orokonui Ecosanctuary in Dunedin, a cooler region. The tuatara is thermally robust, with a broad, if low, active temperature range of $5-30{ }^{\circ} \mathrm{C}$ (Cree, 2014). However, local adaptation to the source location's climate could influence successful establishment at different sites (Miller et al., 2012). We used three standardized progress measures (Miller et al., 2014) to evaluate the short-term success of tuatara translocations and provide an important interim measure of the performance of a cold-adapted reptile in locations warmer than their source ecological region: founder survival, founder growth, and evidence of reproduction.

\section{Methods}

In October 2012176 adult tuatara were translocated from Stephens Island/Takapourewa in the Cook Strait to four sites within their historical range in New Zealand's North Island: Cape Sanctuary, Young Nicks Head Sanctuary, Whangaokeno/East Island, and Maungatautari Ecological Reserve (Fig. 1). Forty head-started (hatched and reared in captivity from wild-sourced eggs) juveniles were also released at Cape Sanctuary and Young Nicks Head Sanctuary.

\section{Source site}

Stephens Island (15o ha, 0-282 altitude) in the Marlborough Sounds is free of invasive predators. It is a designated Nature Reserve of high conservation significance (New Zealand Government, 1977). The island habitat consists of remnant forest, scrubland and pasture (East et al., 1995) and is home to $30,000-50,000$ tuatara, the largest population of this species (Newman, 1982; Gans, 1983). The high density of tuatara (c. 200-2,700 per ha depending on habitat; Moore et al., 2009) and high genetic diversity (MacAvoy et al., 2007) makes the Stephens Island population an ideal source of founders for these and other translocations.

\section{Translocation sites}

Cape Sanctuary is a privately owned, 2,500 ha reserve in Hawkes Bay (o-291 m altitude). Within the sanctuary lies a fenced 1.5 ha enclosure free of invasive predators that contains a fenced $2,000 \mathrm{~m}^{2}$ enclosure. Forty adult tuatara (20 males, 20 females) were released into artificial burrows within the smaller enclosure. One female was suspected to be gravid. Extensive replanting of native flora has restored native shrubs and trees, and there are open areas of non-native grassland. Artificial hides (ground-level shelters) were provided. Twenty head-started juvenile tuatara were also released into a separate $2,000 \mathrm{~m}^{2}$ enclosure of identical construction within the 1.5 ha site. 

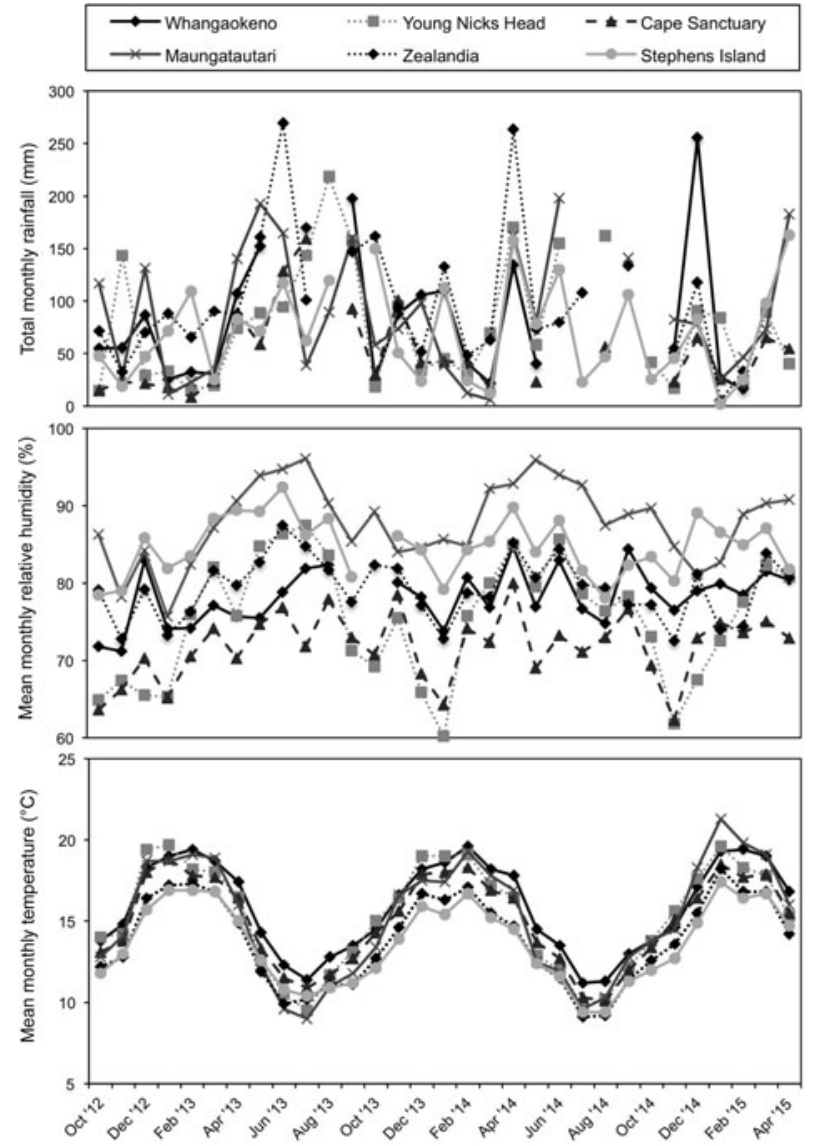

FIG. 2 Total monthly rainfall, mean monthly relative humidity at 9.00 and mean monthly air temperature per site from translocation to final survey: October 2012-April 2015. Rainfall, relative humidity and temperature data from weather stations closest to the translocation sites were obtained from the National Institute of Water and Atmospheric Research Ltd. CliFlo database (NIWA, 2015). Data are not site specific but representative of regional temperatures. All weather station data are interpolated. Data were missing for some months at some stations so lines do not connect all data points. Approximate distances of weather stations from sites: Whangaokeno: Temperature/relative humidity/rainfall $=27 \mathrm{~km}$; Maungatautari: Temperature $=11.6 \mathrm{~km}$, relative humidity $/$ rainfall $=27.5 \mathrm{~km}$; Young Nicks Head: Temperature/relative humidity/ rainfall $=11 \mathrm{~km}$; Cape Sanctuary: Temperature $=5.2 \mathrm{~km}$, relative humidity/rainfall $=5.2 / 20.4 \mathrm{~km}$; ZEALANDIA: Temperature/ relative humidity $/$ rainfall $=1.9 \mathrm{~km}$; Stephens Island:

Temperature/relative humidity/rainfall $=\mathrm{o} \mathrm{km}$ (on site).

Young Nicks Head Sanctuary is located on the privately owned Young Nicks Head Peninsula in Poverty Bay (o-142 m altitude). The 35 ha site is free of invasive predators, surrounded on three sides by steep cliffs and protected by a fence, which runs across the peninsula to exclude predatory mammals such as possums, cats, rats, stoats and mice. Forty-two adult tuatara ( 23 males, 19 females) were released into artificial burrows within the enclosure. Two females were suspected to be gravid. Extensive planting of c. 46,00o native saplings prior to the translocation has begun to restore a closed-canopy, native, coastal forest. Twenty head-started juveniles were also released into artificial burrows in a secure $50 \mathrm{~m}^{2}$ enclosure within the 35 ha site.

Whangaokeno/East Island (o-108 $\mathrm{m}$ altitude) is an unfenced 13 ha protected offshore island Wildlife Refuge Reserve c. $2 \mathrm{~km}$ off the coast of New Zealand's East Cape, free of invasive predators and beyond the swimming distance of introduced mammals (King, 1995). Forty-four adult tuatara ( 25 males, 19 females, none thought to be gravid) were released into artificial burrows at three locations around the island. Seabird colonies on the island have created an extensive network of burrows and there are patches of regenerated native vegetation and open areas of grassland.

Maungatautari is a 3,400 ha, 219-796 m altitude, mainland island sanctuary free of invasive predators in the Waikato region. A predator-proof fence encircles the mountain. Fifty adult tuatara (30 males, 20 females) were released at Maungatautari, with 30 (18 males, 12 females) released into artificial burrows in a 35 ha enclosure on the main mountain and 20 (12 males, 8 females) released into artificial burrows in a $900 \mathrm{~m}^{2}$ enclosure in the Tautari Wetland. Two females were suspected to be gravid, one in the main mountain subgroup and one in the Tautari Wetland subgroup. Mature forest on the main mountain and a variety of native shrubs, trees and open ground in the wetland enclosure provide a range of habitats.

Forty-four adult tuatara were translocated to Orokonui Ecosanctuary, a fenced mainland sanctuary at 28-371 m altitude near Dunedin on the South Island, as part of the translocations from Stephens Island. This population was monitored post-translocation by a research group at the University of Otago (Jarvie et al., 2014).

The tuatara population at ZEALANDIA (145-378 $\mathrm{m}$ altitude; formerly Karori Sanctuary) in Wellington was monitored for comparison purposes throughout this study. The 225 ha sanctuary is free of invasive predators and is surrounded by a predator-proof fence. During 2005-2007 200 adult tuatara were translocated from Stephens Island and released into a fenced 1 ha enclosure and at two unfenced locations in the wider sanctuary. These release sites received 60,40 and 100 tuatara, respectively. Extensive regeneration of native flora within ZEALANDIA has restored a closed canopy forest in much of the valley. The preliminary translocation in December 2005 of 70 adult tuatara was monitored for 1 year (January-December 2006) following release by McKenzie (2007).

\section{Founding population and translocations}

Removal of 176 tuatara for translocation is unlikely to have affected the large Stephens Island population negatively, 
and could relieve interspecific and intraspecific competition at capture locations (Moore et al., 2007). We captured tuatara at night, when they are most active, placed them into individual cloth bags, and recorded their sex, parasite load (ticks Amblyomma sphenodonti and mites Neotrombicula spp.), snout-vent length (SVL), vent-tail length, tail regeneration, and body mass. Sex was determined using secondary sexual characteristics such as body size and presence and prominence of the dorsal crest. Captures were performed in October when females could be carrying shelled eggs and nearing oviposition, and all adult females were palpated by experienced personnel to determine gravidity. To enable individual identification, each animal was fitted with a passive integrated transponder microchip prior to transport, which was inserted subcutaneously on the left side of the body, just forward of the inguinal fold. The injection site was sealed with Vetbond tissue adhesive. Past identification techniques have included toe clipping and bead-tagging, so some individuals also had these identifying marks. On the day of departure, each animal was placed into an individually labelled $500 \mathrm{~mm}$ long aerated postal tube with a piece of damp paper towel to maintain humidity. All animals were transported from Stephens Island to Wellington airport by helicopter and then to the release sites by helicopter, aeroplane, and/or car. Ambient temperature during transport was $15-18^{\circ} \mathrm{C}$. Tuatara were released at translocation sites within 12 hours of departure. They were selected to produce translocated populations with similar mean sizes of animals. Head-started juvenile tuatara were translocated to Cape Sanctuary and Young Nicks Head Sanctuary in March 2012. These animals had been hatched from eggs collected from Stephens Island and incubated at Victoria University of Wellington in Wellington, New Zealand. Juveniles were raised at a captive-rearing facility in semi-natural outdoor enclosures until c. 5 years of age (Nelson et al., 2002; Gartrell et al., 2006). The juveniles were transported in individual plastic containers from the captive-rearing facility in Wellington to the translocation sites by car and released within 24 hours.

\section{Opportunistic monitoring}

Up to four post-release monitoring trips per release site were conducted in the austral spring, summer and autumn during November 2013-May 2015, to survey adult founders. Because of access limitations, Whangaokeno and Stephens Island were only visited twice and Young Nicks Head was visited once (Table 1). Visits lasted 1-10 days, with longer visits facilitating collection of behavioural data (Price 2016) and post-release monitoring information. We conducted searches at night, typically during 20.00-2.00, depending on catch success and weather conditions, using head torches with white light. Searches included the inside of burrows. Head-started juvenile founders were surveyed twice at Young Nicks Head Sanctuary and twice at Cape Sanctuary (Table 1). These surveys were carried out during daylight hours in conjunction with other conservation work at these sites. Captured tuatara were measured, weighed and identified. Animals were visually checked for signs of injury or infection, given a temporary identification (a small mark applied with nontoxic black marker pen at the base of the head) to prevent recapture during the same survey, and returned to their capture site. We also looked for evidence of nesting or breeding where possible.

\section{Data and statistical analyses}

We performed statistical analyses in $R$ v.3.2.2 (R Development Core Team, 2015), using the package lmes for linear mixed-effects models and generalized linear models (Bates et al., 2016). We ran generalized linear models with binomial distributions and recapture (yes/no) as a fixed factor to determine if the body mass of an adult founder on release influenced its recapture during any of the post-release surveys. This was to test the hypothesis that smaller individuals might be harder to recapture following release, because of reduced detection or survival.

We used linear mixed-effects models to estimate differences in adult and juvenile SVL growth rates between study sites following release, using an interaction term between the study site (a four-level categorical variable for adults and two-level for juveniles) and months since release. Individual tuatara was included as a random factor. We ran Kenward-Rogers approximations using the package pbkrtest to obtain parameter-specific probabilities (Halekoh \& Højsgaard, 2012). Only tuatara recaptured and measured following release were included in models of SVL growth. Tuatara of $170-180 \mathrm{~mm} \mathrm{SVL}$ are considered non-sexually mature subadults and growth rates are expected to slow as juveniles reach maturity (Dawbin, 1982). Some translocated adult tuatara had an SVL $<170 \mathrm{~mm}$ (e.g. $167 \mathrm{~mm}$ ) on release and were not included in the adult SVL growth analyses. Juveniles found to have attained an SVL of $\geq 180 \mathrm{~mm}$ were removed from the juvenile growth analyses. Individual body condition over time postrelease was also assessed in adult tuatara. Body condition indices were calculated separately per survey season as the residuals of a linear regression of log-transformed mass and log-transformed SVL (Moore et al., 2007). The body condition indices used in this study met the assumption of linearity $\left(R^{2}>0.82\right)$ for all survey seasons.

Because of the small sample sizes obtained from Whangaokeno and Young Nicks Head Sanctuary in the final post-release survey, we were unable to analyse possible influences of site-specific factors (e.g. population density) on tuatara growth post-release. 
TABLE 1 Seasonal survey data for adult tuatara Sphenodon punctatus (unless stated otherwise) for 2013-2015. Sites are listed from lowest to highest altitude.

\begin{tabular}{|c|c|c|c|c|c|c|c|c|c|}
\hline Site & Area (ha) & Population size $^{1}$ & $\begin{array}{l}\text { Population density } \\
\text { (no. per ha) }\end{array}$ & Season visited ${ }^{2}$ & $\begin{array}{l}\text { No. of } \\
\text { days/nights }\end{array}$ & $\begin{array}{l}\text { No. of } \\
\text { people }\end{array}$ & $\begin{array}{l}\text { No. of } \\
\text { 'person nights' }\end{array}$ & $\begin{array}{l}\text { No. of } \\
\text { captures }\end{array}$ & $\begin{array}{l}\text { No. of captures } \\
\text { per 'person night' }\end{array}$ \\
\hline Whangaokeno & 13 & $44(25 \mathrm{M}, 19 \mathrm{~F})$ & 3.39 & Summer 2015 & 2 & 5 & 10 & 8 & 0.8 \\
\hline Maungatautari & \multirow[t]{3}{*}{0.09} & \multirow[t]{3}{*}{$20(12 \mathrm{M}, 8 \mathrm{~F})$} & \multirow[t]{3}{*}{222} & Spring 2013 & 1 & 3 & 3 & 13 & 4.3 \\
\hline \multirow{2}{*}{ Tautari wetland } & & & & Spring 2014 & 3 & $2-6$ & 12 & 14 & 1.2 \\
\hline & & & & Autumn 2015 & 3 & $2-5$ & 12 & 15 & 1.3 \\
\hline \multirow{2}{*}{$\begin{array}{l}\text { Maungatautari } \\
\text { mountain enclosure }\end{array}$} & \multirow[t]{2}{*}{35} & \multirow[t]{2}{*}{$30(18 \mathrm{M}, 12 \mathrm{~F})$} & \multirow[t]{2}{*}{0.86} & Spring 2013 & 1 & 3 & 3 & 4 & 1.3 \\
\hline & & & & Spring 2014 & 1 & 4 & 4 & 4 & 1 \\
\hline \multirow{2}{*}{ Young Nicks Head } & 0.005 & 20 (juveniles) & 4,000 & Summer 2014 & 1 & 4 & 4 & 20 & 5 \\
\hline & 35 & 42 (adults; $23 \mathrm{M}, 19 \mathrm{~F}$ ) & 1.2 & Summer 2015 & 1 & 3 & 3 & 7 & 2.3 \\
\hline \multirow[t]{4}{*}{ Cape Sanctuary } & \multirow[t]{4}{*}{0.2} & \multirow[t]{4}{*}{$40(20 \mathrm{M}, 20 \mathrm{~F})$} & \multirow[t]{4}{*}{200} & Spring 2013 & 3 & 4 & 12 & 19 & 1.6 \\
\hline & & & & Autumn 2014 & 6 & $2-4$ & 14 & 21 & 1.5 \\
\hline & & & & Spring 2014 & 3 & 4 & 12 & 23 & 1.9 \\
\hline & & & & Autumn 2015 & 3 & $4-5$ & 13 & 23 & 1.8 \\
\hline Stephens Island & 150 & $30,000-50,000$ & $200-333$ & Autumn 2014 & 6 & 3 & 18 & 35 & 1.9 \\
\hline
\end{tabular}

${ }^{1} \mathrm{M}$, males; F, females.

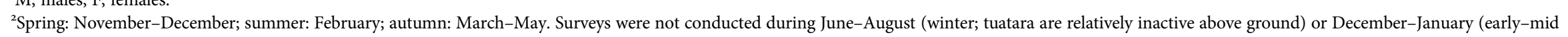
summer; close to the spring and summer visits). 


\section{Results}

\section{Founder survival}

Cumulative recapture rates over 2.5 years post-release were $17-93 \%$ of the adult founding populations and $75-100 \%$ of the juvenile founding populations (Table 2, Fig. 3). Two adult males at Cape Sanctuary died during this study, one from unknown causes and one during surgery following a traumatic eye injury. Recaptures varied across the sites (Table 2). Multiple recaptures may have been higher on Stephens Island but many individuals lacked identifying features (e.g. microchips).

Size at release in October 2012 did not affect recapture in a subsequent survey in the Cape Sanctuary, Young Nicks Head or Maungatautari adult populations, but significantly influenced recapture in the Whangaokeno population $\left(\chi^{2}(1)=6.445\right.$, model $\mathrm{P}=0.011$, estimate $=0.008 \pm 0.003$, $z=2.390, \mathrm{P}=0.017)$. The mean body mass on release of individuals that were not recaptured was lower $($ mean $=281 \pm$ SD $81 \mathrm{~g}$ ) than individuals that were recaptured (mean $=359 \pm \mathrm{SD} 113 \mathrm{~g})$ at Whangaokeno.

\section{Growth and body condition indices}

The mean SVL of females released at Whangaokeno was significantly smaller than the SVL of females at ZEALANDIA (mean difference $=26.88 \pm \mathrm{SD} 9.64 \mathrm{~mm}, t=2.79, \mathrm{P}=0.007$ ), but not significantly different from females at any other translocation sites.
Skeletal growth measured by SVL growth has been negligible at Cape Sanctuary, Maungatuatari and Young Nicks Head Sanctuary and within margins of expected measurement error (c. $10 \mathrm{~mm}$ ) in the 2.5 years since release. The highest SVL growth rates were observed in the Whangaokeno population (male: $6.76 \mathrm{~mm}$ per year; female: $4.37 \mathrm{~mm}$ per year), and were significantly higher than growth rates observed in any other translocated population in this study, including ZEALANDIA (Tables 3 and 4). Growth rates at Cape Sanctuary were significantly lower than those at ZEALANDIA (mean difference = $0.16 \pm$ SD $0.05 \mathrm{~mm}$ per year, $t=-3.04, \mathrm{P}=0.003$ ), but did not differ significantly among any of the other translocation sites. Survey sample sizes for Young Nicks Head and Whangaokeno females were small $(n=2-3$ per site per survey), so the calculated mean growth rates may not be representative of the population.

The body condition of adult founders at most sites generally increased following release: $61 \%$ of Maungatautari individuals, $71 \%$ of Young Nicks Head individuals, and $88 \%$ of Whangaokeno individuals showed increases in body condition indices in the 31 months following release. In contrast, body condition indices for Cape Sanctuary show that $72 \%$ of the adult population experienced declines in body condition post-release. By comparison, $62 \%$ of the animals released at ZEALANDIA during 2005-2007 showed increased body condition at their most recent recapture 8-10 years post-release.

Closer examination of changes in the condition of Cape Sanctuary adult tuatara following release showed that the body mass of $72 \%$ of the 18 individuals recaptured during the first survey in spring 2013 had increased. However, of

TABLE 2 Recaptures of total populations (males and females) and by sex. Number of males and females per site is shown in Table 1. Multiple recaptures refer to an individual captured during more than one post-release survey. Fraction of population captured on Stephens Island is $0.25 \%$ for a total estimated population of 30,000 and $0.15 \%$ for a total estimated population of 50,000. Sex dependent recaptures are not shown for Stephens Island because numbers of males and females are unknown for this location, but mark-recapture data suggest a 1:1 sex ratio (Moore et al., 2009). ZEALANDIA data for 2006 were obtained from McKenzie (2007).

\begin{tabular}{|c|c|c|c|c|c|c|c|}
\hline Site & Population size & No. captured & $\begin{array}{l}\text { No. of } \\
\text { 'person nights' }\end{array}$ & $\%$ of population & $\%$ of females & $\%$ of males & $\begin{array}{l}\text { Multiple } \\
\text { recaptures (\%) }\end{array}$ \\
\hline Whangaokeno & 44 & 17 & 26 & 39 & 26 & 48 & 29 \\
\hline Maungatautari & 50 & 32 & 46 & 64 & 55 & 70 & 59 \\
\hline Tautari wetland & 20 & 19 & 35 & 95 & 100 & 92 & 89 \\
\hline Mountain & 30 & 13 & 11 & 43 & 25 & 56 & 15 \\
\hline Young Nicks Head & 62 & 27 & 11 & 44 & 45 & 40 & \\
\hline Adults & 42 & 7 & 3 & 17 & 11 & 22 & \\
\hline Juveniles & 20 & 20 & 8 & 100 & 100 & 100 & 65 \\
\hline Cape Sanctuary & $60\left(58^{1}\right)$ & $52\left(50^{1}\right)$ & 51 & $87\left(86^{1}\right)$ & 88 & $86\left(85^{1}\right)$ & $73\left(76^{1}\right)$ \\
\hline Adults & $40\left(38^{1}\right)$ & $37\left(35^{1}\right)$ & 51 & $93\left(92^{1}\right)$ & 95 & $90\left(89^{1}\right)$ & $76\left(80^{1}\right)$ \\
\hline Juveniles & 20 & 15 & & 75 & 75 & 75 & 67 \\
\hline Stephens Island & $30-50,000$ & 76 & 39 & $0.15-0.25$ & & & \\
\hline \multicolumn{8}{|l|}{ ZEALANDIA } \\
\hline 2006 & 70 & $44\left(+12\right.$ seen $\left.^{2}\right)$ & $>30$ & 80 & 86 & 74 & \\
\hline 2013-2015 & 200 & 48 & 83 & 24 & 24 & 24 & 48 \\
\hline
\end{tabular}

${ }^{1}$ Altered capture and population numbers as the result of two known deaths of adult male tuatara.

${ }^{2} 12$ tuatara that were sighted but not captured and identified by McKenzie (2007). 


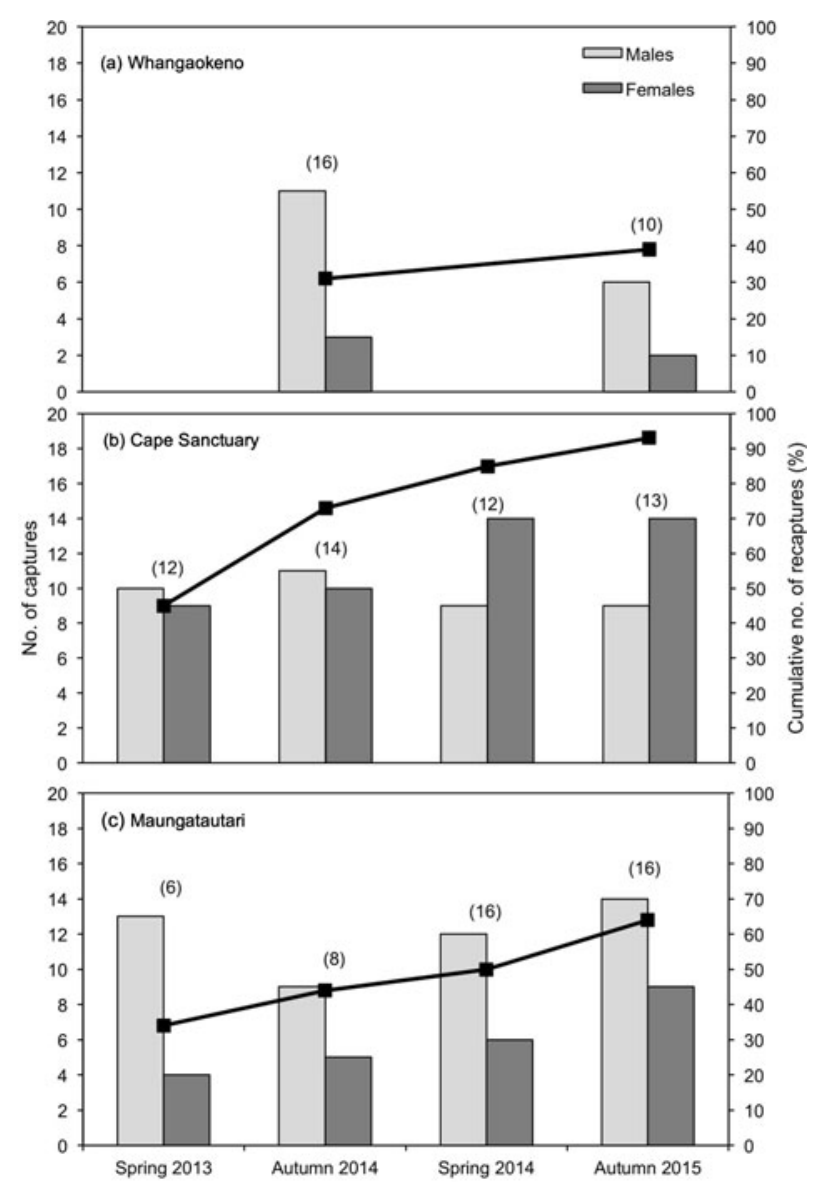

FIG. 3 Adult capture numbers per survey from spring 2013 to autumn 2015 for October 2012 translocation sites visited more than once: (a) Whangaokeno, (b) Cape Sanctuary, (c)

Maungatautari. Bars show number of individuals captured per survey for males and females and black lines show the cumulative number of recaptures as a percentage of the founding population since release. Search effort (person nights) per season shown in parentheses. Two adult males at Cape Sanctuary died during this study, one from unknown causes and one during surgery following a traumatic eye injury. Cumulative recapture numbers for Cape Sanctuary include the individuals that were recaptured but later died and do not include two unidentifiable recaptured animals.

the 11 tuatara captured during both the first and the final post-release surveys, $82 \%$ had lost $5-90 \mathrm{~g}$ in the 17 -month period following the first survey. Overall, $55 \%$ of Cape Sanctuary adults recaptured in autumn 2015 had lost 5-145 g since release (excluding one individual that had lost substantially more and was taken to a wildlife clinic for treatment), reaching a final mean mass of $557 \mathrm{~g}$ for males and $324 \mathrm{~g}$ for females. This is not significantly lower than the mean masses of the same individuals on release (males $=559 \mathrm{~g}$, females $=331 \mathrm{~g})$ and comparable to the mean masses observed in the source population on Stephens Island in the same season (mean males $=603 \mathrm{~g}$, mean females $=321 \mathrm{~g}$ ). The outlying individual was a male that had lost $195 \mathrm{~g}$ and appeared listless and gaunt on discovery. This individual was diagnosed with severe coccidiosis, a parasitic condition that can be exacerbated by overcrowded conditions (B. Gartrell, pers. obs.). In contrast, $91-100 \%$ of tuatara at the other three translocation sites showed mass gains of $25-330 \mathrm{~g}$ or up to $90 \%$ mass increase (relative to mass on release). Of the 23 tuatara recaptured in the final Maungatautari survey, one female showed no mass change since release and one showed a loss of $20 \mathrm{~g}$.

Mean SVLs were not significantly different between juvenile populations on release. Juvenile tuatara at Cape Sanctuary and Young Nicks Head also showed SVL growth and mass increases in the 23-35 months since release, with males on average showing greater mass gain, SVL increase, and SVL growth rates than females in the same population (Table 5). Based on the final juvenile SVL measurements, five of the Young Nicks Head juveniles (four males and one female; 25\%) and seven of the Cape Sanctuary juveniles (five males and two females; $35 \%$ ) have SVLs of $\geq 180 \mathrm{~mm}$, and can be considered adults. Regarding SVL growth, juvenile females at Young Nicks Head grew significantly faster than juvenile females at Cape Sanctuary (mean difference $=-0.44 \pm \mathrm{SD}$ 0.10 $\mathrm{mm}$ per year, $t=4.28$, $\mathrm{P}<0.001$ ), with a mean estimated monthly growth rate of $1.40 \mathrm{~mm}$ per month vs $0.96 \mathrm{~mm}$ per month (or 16.80 $\mathrm{mm}$ per year vs $11.52 \mathrm{~mm}$ per year). There was no significant difference between growth rates of juvenile males at the two sites $(\mathrm{P}>0.05)$, with a mean estimated monthly growth rate of $1.47 \mathrm{~mm}$ per month in Young Nicks Head males and $1.45 \mathrm{~mm}$ per month in Cape Sanctuary males (or $17.64 \mathrm{~mm}$ per year and $17.40 \mathrm{~mm}$ per year). Body condition of juveniles was not assessed because we assumed that excess resources would be utilized for skeletal growth rather than the maintenance of body condition in these animals.

\section{Evidence of reproduction}

We found evidence of reproduction at the four translocation sites surveyed. Split eggshells were found at Cape Sanctuary, Young Nicks Head Sanctuary and on Whangaokeno, suggesting successful hatching. At Maungatautari, signs of nest excavation and a hatchling tuatara were found in the Tautari Wetland enclosure, and on the main mountain we found a nest containing several swollen, potentially viable eggs and a hatchling sheltering inside a burrow. Tuatara nests and eggs have been observed at ZEALANDIA each year since the 2005 release, with the first hatchling observed in March 2009. There have since been regular observations of hatchlings and larger juveniles by ZEALANDIA staff and visitors, but detailed records of these sightings have not been kept. 
TABLE 3 Number of adult animals released at each translocation site, SVL mean, minimum and maximum size on release in October 2012, and estimated SVL growth per month and per year. Mean SVL on release was calculated from all adult tuatara released at each site, whereas estimated mean SVL growth per month and per year were calculated using data obtained from recaptured animals. One female from Maungatautari and two females from ZEALANDIA were omitted from the analysis because their SVLs on release were $<170 \mathrm{~mm}$, classifying them as subadult animals.

\begin{tabular}{|c|c|c|c|c|c|c|c|}
\hline \multirow[b]{2}{*}{ Site } & \multirow[b]{2}{*}{ Sex } & \multirow[b]{2}{*}{ No. adults } & \multicolumn{3}{|c|}{ SVL $(\mathrm{mm})$ on release } & \multirow{2}{*}{$\begin{array}{l}\text { SVL growth (mm } \\
\text { per month) }\end{array}$} & \multirow{2}{*}{$\begin{array}{l}\text { SVL growth }(\mathrm{mm} \\
\text { per year })^{1}\end{array}$} \\
\hline & & & Mean \pm SE & Min. & Max. & & \\
\hline \multirow[t]{2}{*}{ Cape Sanctuary } & Male & 20 & $228.45 \pm 4.44$ & 173 & 259 & -0.021 & -0.252 \\
\hline & Female & 20 & $205.00 \pm 3.18$ & 180 & 223 & -0.109 & -1.308 \\
\hline \multirow[t]{2}{*}{ Maungatautari } & Male & 30 & $229.75 \pm 3.63$ & 194 & 270 & 0.000 & 0.002 \\
\hline & Female & 19 & $199.54 \pm 3.27$ & 175 & 233 & 0.001 & 0.008 \\
\hline \multirow[t]{2}{*}{ Whangaokeno } & Male & 25 & $220.36 \pm 3.98$ & 194 & 250 & 0.563 & 6.756 \\
\hline & Female & 19 & $186.92 \pm 3.28$ & 174 & 209 & 0.364 & 4.368 \\
\hline \multirow[t]{2}{*}{ Young Nicks Head } & Male & 23 & $230.83 \pm 4.16$ & 179 & 263 & -0.007 & -0.084 \\
\hline & Female & 19 & $197.79 \pm 3.28$ & 174 & 225 & -0.071 & -0.852 \\
\hline \multirow[t]{2}{*}{ ZEALANDIA $^{2}$} & Male & 104 & $230.13 \pm 3.18$ & 170 & 280 & 0.036 & 0.432 \\
\hline & Female & 94 & $194.56 \pm 1.96$ & 172 & 280 & 0.047 & 0.570 \\
\hline
\end{tabular}

${ }^{1}$ Calculated by multiplying monthly mean growth estimates by 12 .

${ }^{2}$ On release data were calculated from animals released in 2005 and 2007.

TABLE 4 Results of linear mixed effects models run individually by sex to compare growth rates between recaptured Whangaokeno tuatara and recaptured tuatara from other translocation sites.

\begin{tabular}{|c|c|c|c|c|c|c|}
\hline Site & Sex & Sample size ${ }^{1}$ & Estimate $^{2}$ & Standard error & $T$ value & $\mathrm{P}$ \\
\hline \multirow[t]{2}{*}{ Cape Sanctuary } & Males & 18 & -0.582 & 0.139 & -4.184 & $<0.001$ \\
\hline & Females & 19 & -0.478 & 0.144 & -3.314 & 0.001 \\
\hline \multirow[t]{2}{*}{ Maungatautari } & Males & 21 & -0.562 & 0.135 & -4.156 & $<0.001$ \\
\hline & Females & 10 & -0.364 & 0.151 & -2.411 & 0.018 \\
\hline \multirow[t]{2}{*}{ Young Nicks Head } & Males & 5 & -0.571 & 0.185 & -3.089 & 0.003 \\
\hline & Females & 2 & -0.437 & 0.213 & -2.052 & 0.044 \\
\hline \multirow[t]{2}{*}{ ZEALANDIA } & Males & 21 & -0.528 & 0.116 & -4.555 & $<0.001$ \\
\hline & Females & 20 & -0.318 & 0.136 & -2.347 & 0.022 \\
\hline
\end{tabular}

${ }^{1}$ Number of individuals recaptured at least once following release on which these analyses are based (Whangaokeno male sample size $=18$, female sample size $=5$ ).

${ }^{2}$ Difference in monthly growth rate between Whangaokeno and recaptured individuals from other sites (all differences are statistically significant).

TABLE 5 Mean \pm SE juvenile male and female mass and SVL of tuatara at Cape Sanctuary and Young Nicks Head Sanctuary at release (Cape Sanctuary: $M=7, F=13$. Young Nicks Head: $M=7, F=12$ ) and at the final post-release survey (Cape Sanctuary: $M=5, F=8$. Young Nicks Head: $M=7, F=12$ ), and mean changes from release to final survey. Data are based on individuals that were captured in the final survey. The final surveys at Young Nicks Head and Cape Sanctuary were done 23 and 35 months post-release, respectively. The final Cape Sanctuary juvenile survey was conducted by Gibson et al. (2015). Sex was determined by laparoscopy prior to release. The sex of one Young Nicks Head individual could not be determined so its data have not been used. Multiple juveniles reached adult size over the course of the post-release surveys, as indicated by the final mean SVL.

\begin{tabular}{|c|c|c|c|c|c|c|c|}
\hline \multirow[b]{2}{*}{ Site } & \multirow[b]{2}{*}{ Sex } & \multicolumn{3}{|l|}{ Juvenile mass } & \multicolumn{3}{|l|}{ Juvenile SVL } \\
\hline & & $\begin{array}{l}\text { Release mean } \pm \\
\mathrm{SE}(\mathrm{g})\end{array}$ & $\begin{array}{l}\text { Final mean } \pm S E \\
(\mathrm{~g})\end{array}$ & $\begin{array}{l}\text { Mean change, } g \\
(\%)\end{array}$ & $\begin{array}{l}\text { Release mean } \pm S E \\
(\mathrm{~mm})\end{array}$ & $\begin{array}{l}\text { Final mean } \pm S E \\
(\mathrm{~mm})\end{array}$ & $\begin{array}{l}\text { Mean change, } \\
\mathrm{mm}(\%)\end{array}$ \\
\hline Cape & $\mathrm{M}$ & $103.1 \pm 8.1$ & $225.0 \pm 19.6$ & $129.2(125)$ & $145.3 \pm 2.8$ & $193.4 \pm 4.4$ & $47.6(33)$ \\
\hline Sanctuary & $\mathrm{F}$ & $87.2 \pm 3.4$ & $183.8 \pm 6.3$ & $93.2(107)$ & $138.3 \pm 1.7$ & $174.8 \pm 1.8$ & $35.5(26)$ \\
\hline Young Nicks & M & $94.7 \pm 4.4$ & $218.7 \pm 11.7$ & $124.1(131)$ & $143.1 \pm 2.2$ & $180.7 \pm 2.7$ & $37.6(26)$ \\
\hline Head & $\mathrm{F}$ & $87.1 \pm 5.4$ & $184.9 \pm 10.5$ & $98.9(114)$ & $137.3 \pm 2.8$ & $171.0 \pm 2.5$ & $33.8(25)$ \\
\hline
\end{tabular}

\section{Discussion}

We found evidence that translocation to a warmer location was generally successful in the short-term, based on observations of survival, growth, and reproduction. However, tuatara typically mature at 11-13 years of age, and the adult populations described here have been monitored for $28-31$ months, equating to only $5 \%$ of the species generation 
interval (40-50 years). Longer-term studies are necessary to determine the self-sustainability of these populations.

By all short-term measures, most translocations are progressing favourably. There have been moderate to high numbers of recaptures, SVL growth and mass gain results have been variable across sites, and there is evidence of successful reproduction at all sites. However, we cannot confirm if observed hatchlings were the result of post-translocation matings or eggs laid by females translocated while gravid, with the exception of Whangaokeno, which received no gravid females. Growth metrics generally increased for individuals at Maungatautari, Whangaokeno and Young Nicks Head. However, the Cape Sanctuary population presented a negligible growth rate, declining overall body condition, and weight loss in the majority of recaptured animals.

Climate change predictions for New Zealand suggest that, among other factors, surface air temperatures will continue to rise, rainfall will increase in some regions and decrease in others, and drought frequency and fire danger will increase (Reisinger et al., 2014). Our aim in investigating these four cohorts of tuatara translocated to comparatively warmer climates outside their ecological region was to determine if their success or failure could be used as a surrogate for understanding potential effects of climate warming. Our results suggest a cause for cautious optimism regarding the tuatara's ability to adapt to warmer climates, based on these short-term responses. However, the robustness of this conclusion is limited because of our study size and duration. Further research is needed to understand longer term effects on survival and reproduction, including effects of local climatic factors, drought, invertebrate density, and embryonic development.

The comparatively low number of recaptures at Whangaokeno, Young Nicks Head Sanctuary and in the Maungatautari mountain enclosure can be attributed to survey limitations imposed by these larger, less densely populated sites. Tuatara are cryptic, burrow-dwelling, primarily nocturnal reptiles. Combined with factors like the low population densities and areas of inaccessible habitat (e.g. steep slopes and dense vegetation) at these locations, surveyor access was hindered and tuatara were probably better able to conceal themselves, a problem also observed following previous translocations (Nelson et al., 2002; Miller et al., 2010). Non-detection does not equate to mortality (Towns \& Ferreira, 2001), and the increasing cumulative recaptures observed indicate that previously unseen founders are recaptured with each successive survey, suggesting that future surveys could uncover animals not seen since translocation. This emphasizes the importance of repeat surveys to increase the chance of detection, improve cumulative recapture numbers, and obtain reliable measures of survival.

The low recapture numbers in some populations meant we could not analyse potential relationships between postrelease SVL and mass growth and site-specific factors (e.g. population density, air temperature). However, several factors are known to be important for population viability in tuatara and other reptiles that may explain variation between sites in this study. Firstly, resource availability and density-dependent competition play a large role in individual growth and reproductive potential. Density-dependent responses to competition for limited resources are thought to be responsible for significant declines in body condition of natural populations of tuatara, including those on Stephens Island (Hoare et al., 2006; Moore et al., 2007). Relief from density-dependent competition was considered a potential driving factor behind the large mass increases documented in adult tuatara moved from the densely populated North Brother Island to Titi Island (Nelson et al., 2002).

The other major factor is local climate. Consistent with the hypothesis that environmental and other site-specific factors could have influenced post-release growth, smaller mean increases in mass and lower or negligible growth rates were seen in the Cape Sanctuary and Maungatautari Tautari Wetland population, which host comparatively higher population densities and have cooler climates than Young Nicks Head Sanctuary and Whangaokeno. Given that Cape Sanctuary hosted a similar population density as the Maungatautari Tautari Wetland, the low growth rates and declining weights observed in multiple individuals could be explained by limited resource availability and high intraspecific competition. The density of tuatara within the Cape Sanctuary adult enclosure is one of the highest of the translocated populations (200 per ha) and the observed change in body mass (initial increase followed recent declines, in many instances to below an individual's release weight), suggests that an initially plentiful supply of prey could have dwindled, leaving tuatara in competition for limited resources. However, although there is anecdotal evidence for a decline in the number of snails present in the Cape Sanctuary enclosure over time, invertebrate surveys were not part of this study, so this hypothesis cannot be confirmed. It is also feasible that a more site-specific issue such as drought over the summer months could have influenced humidity and water availability, invertebrate prey populations and consequently tuatara physical condition. To reduce population density and increase resource availability we make a management recommendation to remove or modify the fence surrounding the Cape Sanctuary adult tuatara enclosure to enable dispersal into the wider site. Future monitoring should also include measures of the invertebrate prey base.

The Whangaokeno population exhibited the most substantial growth of all four translocated populations, demonstrating that up to now movement to a considerably warmer climate has had no observable negative consequences for these tuatara. Because body size and growth in reptiles is influenced by environmental factors such as resource 
availability and air temperature, which can vary with population density, site size and location (Nelson et al., 2002; Cree, 2014), the greater growth exhibited by the Whangaokeno tuatara could be attributed to the site's warmer climate. Combined with a low population density (low intra-specific competition) these factors could contribute to the faster growth rates observed. Alternatively, given that animals with larger SVLs on release were more likely to be recaptured on Whangaokeno, a biased sampling effort as a result of size-dependent differences in habitat use or detection ability could be responsible.

Continued monitoring of SVL growth in the Whangaokeno population will be useful to determine the cause of the linear relationship between tuatara SVL and island size, with larger tuatara found on larger islands (Cree, 2014). It has been hypothesized that variations in habitat, resource abundance and stability, or the presence or absence of introduced predators could be responsible; however, these relationships are more likely to be visible for populations at carrying capacity rather than for those that have been translocated recently (Cree, 2014).

We focused on short-term measures of success to assess the progress of the translocated animals monitored in this study. Long-term success is dependent on self-sustaining populations. The positive outcomes in this study align with previous successes in tuatara translocations within the same climate region. Post-translocation surveys on Titi Island reported increases in founder size, evidence of reproduction, and high recaptures over 5 years $(57 \%$; Nelson et al., 2002) and at 12 years (63\%; Miller et al., 2010) post-release. Similarly, 9 years after a translocation to Matiu/Somes Island, $60 \%$ of founders were recaptured, animals had grown, and evidence of reproduction was observed (Miller et al., 2010). Data collected from ZEALANDIA have also shown size gains in translocated tuatara 1 year after release (McKenzie, 2007) and during this study. If the populations in this study (translocated in 2012) continue to show similar progress, the trends in other translocated tuatara populations bode well for longer-term translocation success. The Western Swamp tortoise Pseudemydura umbrina and Duvaucel's gecko Hoplodactylus duvaucelii are similarly long-lived, range restricted reptiles vulnerable to introduced predators and habitat loss (Burbidge \& Kuchling, 2004; Bell \& Herbert, 2017). Since the 1990s, following translocations to fenced sites, the P. umbrina population has increased substantially (Burbidge \& Kuchling, 2004), although postrelease monitoring $>20$ years is needed to determine longterm success. Conversely, despite initially poor recaptures, 11-15 years post release the 40 translocated $H$. duvaucelli are now a self-sustaining population of c. 245 individuals (Bell \& Herbert, 2017).

Predictors of translocation success can include founder group size, habitat suitability, dispersal behaviour, translocation motivation, and the age and source of founders (Germano \& Bishop, 2008). In addition, physiologically suitable sites within a species' active range are particularly relevant for cold-adapted ectothermic species and it is important that animals have a range of thermal conditions available (Towns \& Ferreira, 2001). Tuatara demonstrate a broad, if low, active body temperature range and the sites to which they have been translocated all currently experience temperatures favourable to behaviours such as basking and nesting, and artificial refuges offer shelter if required. The fact that several tuatara populations have so far demonstrated high survival rates, growth, and some evidence of reproduction at sites that can exceed mean temperatures on Stephens Island by $2-4{ }^{\circ} \mathrm{C}$ suggests that these warmer climates have not negatively affected the survival of translocated individuals, that possible local adaptations to the Stephens Island climate have not impeded their ability to establish at new sites, and that tuatara may be capable of tolerating the warmer air temperatures predicted for the 2100 . However, long-term we need to consider the risks that a warming climate will pose to embryonic development and the resulting sex ratios (this is a species with temperaturedependent sex determination; Grayson et al., 2014). It is also important to note that the declining condition of individuals in the Cape Sanctuary population could be attributed to environmental factors such as drought, which is predicted to occur more frequently under climate change scenarios (IPCC, 2014). As such, it may not be air temperatures that directly affect the survival of cold-adapted tuatara as climate change progresses, but the effect on associated abiotic factors and impacts on habitat, disease and prey populations. The translocation of Stephens Island individuals to the cooler Orokonui Ecosanctuary site has been progressing well in the short term (Jarvie et al., 2015) and will probably facilitate successful nest incubation in the future (Jarvie et al., 2014); therefore further translocations to southern sites, which are not expected to experience the same high temperatures or abiotic extremes, is a promising long-term conservation strategy.

Although several studies and reviews suggest translocations can be used as a management tool to mitigate the negative impacts of climate change (Loss et al., 2011; Thomas, 2011), we found no other studies in the literature that have utilized translocations to examine the effects that a warming climate could have on a species. Little research has been conducted on this subject and impacts of such translocations need to be monitored carefully and across different taxa to identify any generalized patterns that can be used to model such effects more comprehensively. Understanding shortterm effects of climate shifts on long-lived species is important for directing conservation efforts, particularly where populations are vulnerable, dispersal is restricted, and human intervention is necessary. 
Acknowledgements We thank the Department of Conservation (permits NM-18922-CAP and 36857-FAU), landowners and iwi, including Ngāti Koata (kaitiaki of tuatara from Stephens Island/ Takapourewa), the Maungatautari Ecological Island Trust Board and Mana Whenua representatives, Ngāti Mihiroa, Ngai Tāmanuhiri, Ngāti Porou, the Wellington Tenths Trust, ZEALANDIA (formerly Karori Sanctuary), Ecoworks NZ Ltd., Wildbase Hospital, and Ngā Manu Nature Reserve for providing us with permits, consultations, assistance and approvals. For funding to SJP we thank the Commonwealth Scholarships Commission, the Victoria University of Wellington Faculty of Science, the Victoria University of Wellington Centre for Biodiversity and Restoration Ecology, and the Society for Research on Amphibians and Reptiles in New Zealand. We thank Susan Keall, Colin Thompson, Noela McGregor, Polly Hall, Emma Dent, Francesco Civilini, Sarah Alexander, Rebecca Webster, Zoe Grange, Emma Rowell, Hal Hovell, Te Taiawatea Moko-Mead, Bart Cox, Tamsin Ward-Smith, John Berry, Nick Cabot and the numerous volunteers and sanctuary staff who assisted with the capture, transport, release and monitoring of the tuatara.

Author contributions Organization of the 2012 translocations: NJN; study conception: SJP, KLG, BDG and NJN; data collection, analysis, and interpretation: SJP with supervision by NJN and KLG; writing: BDG and SJP; revisions and comments: NJN, KLG and BDG.

\section{Conflicts of interest None.}

Ethical standards This research complied with the Oryx Code of Conduct and was conducted with approval from the Victoria University of Wellington Animal Ethics Committee (Permit No. 2012R33) and the New Zealand Department of Conservation (permits NM-18922-CAP and 36857-FAU).

\section{References}

Bates, D., Maechler, M., Bolker, B. \& Walker, S. (2016) Package 'Ime4': Linear Mixed-Effects Models using 'Eigen' and S4. Https:// cran.r-project.org/web/packages/lme4/lme4.pdf [accessed: 16 May 2018].

Bell, T.P. \& Herbert, S.M. (2017) Establishment of a self-sustaining population of a long-lived, slow-breeding gecko species (Diplodactylidae: Hoplodactylus duvaucelii) evident 15 years after translocation. Journal of Herpetology, 51, 37-46.

Burbidge, A.A. \& Kuchling, G. (2004) Western Swamp Tortoise (Pseudemydura Umbrina) Recovery Plan. 3rd edition. Department of Conservation \& Land Management, Western Australia, Perth, Australia.

Cree, A. (2014) Tuatara: Biology and Conservation of a Venerable Survivor. Canterbury University Press, Christchurch, New Zealand.

Cree, A. \& Butler, D. (1993) Tuatara Recovery Plan (Sphenodon spp.). Threatened Species Recovery Plan Series No. 9, Department of Conservation, Wellington, New Zealand.

Cree, A., Cockrem, J.F. \& Guillette, L.J. (1992) Reproductive cycles of male and female tuatara (Sphenodon punctatus) on Stephens Island, New Zealand. Journal of Zoology, 226, 199-217.

DAwBin, W.H. (1982) The tuatara Sphenodon punctatus: aspects of life history, growth and longevity. In New Zealand Herpetology (ed. D. G. Newman), pp. 237-250. New Zealand Wildlife Service Occasional Publication No. 2, Wellington, New Zealand.
Deutsch, C.A., Tewksbury, J.J., Huey, R.B., Sheldon, K.S., GHalambor, C.K., HaAK, D.C. \& Martin, P.R. (2008) Impacts of climate warming on terrestrial ectotherms across latitude. Proceedings of the National Academy of Sciences of the United States of America, 105, 6668-6672.

East, K.T., East, M.R. \& Daugherty, C.H. (1995) Ecological restoration and habitat relationships of reptiles on Stephens Island, New Zealand. New Zealand Journal of Zoology, 22, 249-261.

Gans, C. (1983) Is Sphenodon punctatus a maladapted relict? In Advanced in Herpetology and Evolutionary Biology: Essays in Honour of Ernest E. Williams (eds A. Mijata \& K. Rhodin), pp. 613620. Museum of Comparative Biology, Cambridge, Massachusetts, USA.

Gartrell, B.D., Jillings, E., Adlington, B.A., Mack, H. \& NeLson, N.J. (2006) Health screening for a translocation of captive-reared tuatara (Sphenodon punctatus) to an island refuge. New Zealand Veterinary Journal, 54, 344-349.

Germano, J.M. \& Bishop, P.J. (2008) Suitability of amphibians and reptiles for translocation. Conservation Biology, 23, 7-15.

Gibson, J., Hall, E., Johnson, E. \& McLean, C. (2015) Assessment of Cape Sanctuary juvenile tuatara population: Health, habitat, and management. MSc thesis. Victoria University of Wellington, Wellington, New Zealand.

Grayson, K.L., Mitchell, N.J., Monks, J.M., Keall, S.N., Wilson, J.N. \& Nelson, N.J. (2014) Sex ratio bias and extinction risk in an isolated population of tuatara (Sphenodon punctatus). PLoS ONE, 9, e94214.

Halekoh, U. \& HøJSGAard, S. (2012) PBKRTEST: parametric bootstrap and Kenward Roger based methods for mixed model comparison. Https://cran.r-project.org/package=pbkrtest [accessed 8 June 2018].

Hoare, J.M., Pledger, S., Keall, S.N., Nelson, N.J., Mitchell, N.J. \& DAUgherty, C.H. (2006) Conservation implications of a long-term decline in body condition of the Brothers Island tuatara (Sphenodon guntheri). Animal Conservation, 9, 456-462.

Huey, R.B., Kearney, M.R., Krockenberger, A., Holtum, J.A.M., Jess, M. \& Williams, S.E. (2012) Predicting organismal vulnerability to climate warming: roles of behaviour, physiology and adaptation. Philosophical Transactions of the Royal Society of London B: Biological Sciences, 367, 1665-1679.

IPCC (2014) Summary for Policymakers. In Climate Change 2014: Synthesis Report. Contribution of Working Groups I, II and III to the Fifth Assessment Report of the Intergovernmental Panel on Climate Change (eds R.K. Pachauri \& L.A. Meyer), p. 151. IPCC, Geneva, Switzerland.

IUCN/SSC (2013) Guidelines for reintroductions and other conservation translocations. Version 1.o. IUCN Species Survival Commission, Gland, Switzerland.

Jarvie, S., Besson, A.A., Seddon, P.J. \& Cree, A. (2014) Assessing thermal suitability of translocation release sites for egg-laying reptiles with temperature-dependent sex determination: a case study with tuatara. Animal Conservation, 17, 48-55.

Jarvie, S., Senior, A.M., Adolph, S.C., Seddon, P.J. \& Cree, A. (2015) Captive-rearing affects growth but not survival in translocated juvenile tuatara. Journal of Zoology, 297, 184-193.

KING, C.M. (1995) The Handbook of New Zealand Mammals. Oxford University Press, Auckland, New Zealand.

Loss, S.R., Terwilliger, L.A. \& Peterson, A.C. (2011) Assisted colonization: integrating conservation strategies in the face of climate change. Biological Conservation, 144, 92-100.

MacAvoy, E.S., McGibbon, L.M., Sainsbury, J.P., Lawrence, H., Wilson, C.A., Daugherty, C.H. \& Chambers, G.K. (2007) Genetic variation in island populations of tuatara (Sphenodon spp) 
inferred from microsatellite markers. Conservation Genetics, 8 , 305-318.

McKenZie, K.L. (2007) Returning tuatara (Sphenodon punctatus) to the New Zealand mainland. Unpublished Masters thesis. Victoria University of Wellington, Wellington, New Zealand.

Miller, K.A., Gruber, M.A.M., Keall, S.N., Blanchard, B. \& Nelson, N.J. (2010) Changing taxonomy and the need for supplementation in the management of re-introductions of Brothers Island tuatara in Cook Strait, New Zealand. In Global re-introduction perspectives: additional case-studies from around the globe (ed. P.S. Soorae), pp. 93-97. IUCN/SSC Reintroduction Specialist Group, Gland, Switzerland and Environment Agency Abu Dhabi, Abu Dhabi, United Arab Emirates.

Miller, K.A., Miller, H.C., Moore, J.A., Mitchell, N.J., Cree, A., Allendorf, F.W. et al. (2012) Securing the demographic and genetic future of tuatara through assisted colonization. Conservation Biology, 26, 790-798.

Miller, K.A., Bell, T.P. \& Germano, J.M. (2014) Understanding publication bias in reintroduction biology by assessing translocations of New Zealand's herpetofauna. Conservation Biology, 28, 1045-1056.

Moore, J.A., Hoare, J.M., Daugherty, C.H. \& Nelson, N.J. (2007) Waiting reveals waning weight: monitoring over 54 years shows a decline in body condition of a long-lived reptile (tuatara, Sphenodon punctatus). Biological Conservation, 135, 181-188.

Moore, J.A., Daugherty, C.H. \& Nelson, N.J. (2009) Large male advantage: phenotypic and genetic correlates of territoriality in tuatara. Journal of Herpetology, 43, 570-578.

Nelson, N.J., Keall, S.N., Brown, D. \& Daugherty, C.H. (2002) Establishing a new wild population of tuatara (Sphenodon guntheri). Conservation Biology, 16, 887-894.

New Zealand Government (1977) Reserves Act. New Zealand.

Newman, D.G. (1982) Tuatara, Sphenodon punctatus, and burrows, Stephens Island. In New Zealand Herpetology (ed. D.G. Newman), pp. 213-221. New Zealand Wildlife Service, Dept. of Internal Affairs Occasional Publication 2, Wellington, New Zealand.

NIWA (2015). CliFlo: NIWA's National Climate Database on the Web. Http://cliflo.niwa.co.nz/ [accessed 26 November 2015].

R Development Core Team (2015) R: A language and environment for statistical computing. R Foundation for Statistical Computing,

Vienna, Austria. Https://www.r-project.org/ [accessed 19 April 2016].

Reisinger, A., Kitching, R., Chiew, F., Hughes, L., Newton, P., Schuster, S. et al. (2014) Australasia. In Climate Change 2014: Impacts, Adaptation, and Vulnerability. Part B: Regional Aspects. Contribution of Working Group II to the Fifth Assessment Report of the Intergovernmental Panel on Climate Change (eds V. Barros, C. Field, D. Dokken, M. Mastrandrea, K. Mach, T. Bilir, M. Chatterjee, K. Ebi, Y. Estrada, R. Genova, B. Girma, E. Kissel, A. Levy, S. MacCracken, P. Mastrandrea \& L. White), pp. 1371-1438. Cambridge University Press, Cambridge, UK and New York, USA. SEddon, P.J. (2010) From reintroduction to assisted colonization: moving along the conservation translocation spectrum. Restoration Ecology, 18, 796-802.

Seddon, P.J., Strauss, W.M. \& Innes, J. (2012) Animal translocations: what are they and why do we do them? In Reintroduction Biology: Integrating Science and Management (eds J. Ewen, D. Armstrong, K. Parker \& P. Seddon), pp 17-23. Wiley Blackwell, Oxford, UK.

Tном аs, C.D. (2011) Translocation of species, climate change, and the end of trying to recreate past ecological communities. Trends in Ecology \& Evolution, 26, 216-221.

Towns, D.R. \& Ferreira, S.M. (2001) Conservation of New Zealand lizards (Lacertilia: Scincidae) by translocation of small populations. Biological Conservation, 98, 211-222.

Towns, D.R., Miller, K.A., Nelson, N.J. \& Chapple, D.G. (2016) Can translocations to islands reduce extinction risk for reptiles? Case studies from New Zealand. Biological Conservation, 204, 120-127. 